\title{
Assessment of Information Needs of Shea Butter Processors' on Modern Processing Technologies in North Central Agro-Ecological Zone of Nigeria
}

\author{
L. Igene ${ }^{1}$, O. Solomon ${ }^{1}$, M. Osifo ${ }^{1} \&$ B. E. Akagbosu ${ }^{1}$ \\ ${ }^{1}$ Extension Division, Nigerian Institute for Oil Palm Research (NIFOR), Benin City, Edo State, Nigeria \\ Correspondence: Igene Lucky, NIFOR, Benin City, Edo State, Nigeria. E-mail: igenelucky@gmail.com
}

Received: October 19, 2018 Accepted: November 8, 2018 Online Published: December 20, 2018

doi:10.5539/sar.v8n1p59

URL: https://doi.org/10.5539/sar.v8n1p59

\begin{abstract}
To ensure sustainable shea butter production in North Central Agro-ecological zone of Nigeria using modern shea butter processing technologies necessitated this study. The major objective of the study was to identify the information needs of shea butter processors' on modern shea butter processing technologies whilst examining the respondents' socio-economic characteristics, ascertaining their awareness, areas of information needs, sources of information, and perception on the effect of inadequate information on modern processing technologies were the specific objectives. Primary data were collected from 216 processors' using multi-stage sampling procedure. The data were analysed using descriptive and inferential statistics. Findings revealed that most (90.3\%) of the processors' were females, young and married with little or no formal education and having between 6 to 15 years of processing experience. Respondents obtained information mostly from fellow processors $(\overline{\mathrm{X}}=70)$ and cooperative societies $(\bar{X}=67)$. Perceived areas of information need include kneading $(\bar{X}=89)$, crushing $(\bar{X}=88)$, roasting $(\overline{\mathrm{X}}=85)$ and milling $(\overline{\mathrm{X}}=84)$. Perceived effects of inadequate information on modern processing technologies were low yield of shea butter $(\overline{\mathrm{X}}=78)$, low income $(\overline{\mathrm{X}}=76)$, and local use of local technologies $(\overline{\mathrm{X}}$ $=71)$ and poor packaging of shea butter $(\bar{x}=78)$. Respondents' sex $\left(\chi^{2}=22.076,0.000\right)$, educational level $\left(\chi^{2}=\right.$ $86.983,0.000)$ and years of processing experience $\left(\chi^{2}=22.076,0.000\right)$ had significant association with their perception of information needs. Creation of awareness on modern shea butter processing technologies through the use of more radio programmes aired at appropriate time and the use of leaflets produced both in English and local languages is recommended.
\end{abstract}

Keywords: information, needs, processors, shea butter, modern processing technologies

\section{Introduction}

The basic human need after air, water, food and shelter according to Stanley (1990) is information. Man requires information to be able to manipulate factors of production such as land, labour and capital resources into meaningful and productive use (Camble, 1992). The steady flow of accurate, understandable and factual information according to Adedoyin (1990) links the scientist with farmers, in which for any true agricultural progress, farmers must know, understand, and act on this information. Therefore, how people progress in whatever they are doing depends largely upon the availability and access to accurate and reliable information (Ajayi et al., 2010).

In the development of any information activity, information need identification is the first step and provides many things for the farmer. The analysis determines the information contents and how deficient farmers are in these contents and the sequence of tasks provides the sequence of information activity (Ajayi et al., 2010). Morris and Stilwell (2003) posited that farmers are in the best position to determine whether any information is of greater value to meet their needs. Information is one of the most valuable resources in rural development (Morrow et al., 2002), and can assist small farmers take informed decisions and appropriate action (Harris et al., 2001).

Shea tree (Vitellaria paradoxa) grows in 19 countries across the African continent, namely Benin, Ghana, Chad, Burkina Faso, Cameroon, Central African Republic, Ethiopia, Guinea Bissau, Cote D'Ivoire, Mali, Niger, Nigeria, Senegal, Sierra Leone, Sudan, Togo, Uganda, DR Congo and Guinea (Eneh, 2010). In Nigeria, shea tree is widely known, valued and exploited by the natives in all the areas where it grows (Ololade and Ibrahim, 
2014).

The growing increase in the demand of shea butter on the international market has made the product an immerging economic product. This is mainly so because it has found many uses in a wide range of food products, medicinal preparation and cosmetic industry (Eneh, 2010; Ololade and Ibrahim, 2014). In addition, the European Union considered shea butter as one of the six vegetable oils to be used as a cocoa butter equivalent (CBE).

In order to meet the demand of local and international markets, small scale processors across the producing states in Nigeria need to use modern processing technologies to process shea fruits into butter. However, the use of modern processing technologies poses challenges for small scale shea butter processors who require information and training to acquire the necessary skills to utilize the equipment, financial assistance and access to input and output markets.

Also, Aina (2004) opined that the poor access to information and training by small scale farmers was due to the initial policy formulation of Agricultural Development Programme (ADP) which was mainly directed on arable crop production. Even when exposed to information, cursory observation revealed that most information disseminated by ADPs, Nigerian Institute for Oil Palm Research (NIFOR) and other related institutions are usually given without needs identification and this has implication for capacity building. Similarly, according to Ozowo, (2004) as quoted by Ajayi et al., (2010), "no one can categorically claim to know all the information needs of farmers especially in an information dependent sector like agriculture where there are new and rather complex problems facing farmers every day". Identifying information needs of shea butter processors could stimulate research activities targeted at solving processors' problems as well as assisting agencies involved in extension services to disseminate and design appropriate information programme for processors. This is because competency in the various aspect of modern shea butter processing considering its huge potential could contribute to the poverty alleviation policy of government through improved income of processors.

\subsection{Objective of the Study}

The major objective of the study was to assess the information needs of shea butter processors' on modern processing technologies in North Central Agro-ecological zone of Nigeria. The specific objectives were to:

1. Examine the selected socio-economics characteristics of the respondents.

2. Ascertain respondents' awareness of the selected modern shea butter processing technologies.

3. Identify areas of information needs of respondents' on the selected modern shea butter processing technologies.

4. Investigate respondent's sources of information on the selected modern shea butter processing technologies.

5. Ascertain respondents' perception on the effect of inadequate information on the selected modern shea butter processing technologies.

\subsection{Hypothesis of the Study}

The hypothesis is stated in the null form:

$\mathrm{Ho}_{1}$ : There is no significant relationship between respondents' sex, educational level and years of processing experience and their information needs on modern shea butter processing technologies.

\section{Methodology}

The study was conducted in North-central Agro-ecological zone of Nigeria. This zone consists of seven states namely Kwara, Kogi, Plateau, Nassarawa, Benue, Niger and FCT Abuja. The population size of this region is about twenty million based on National Population Commission survey, NPC (2007). Respondents for the study were selected through a multi-stage sampling procedure. The first stage involves purposive selection of two states (Kwara and Niger) from the seven states that made up the North Central Agro-ecological zone of Nigeria because of the high concentration of shea butter processing activities. The second stage involves purposive selection of three Local Government Areas (LGAs) from each of the state to obtain six LGAs based on the high presence of shea butter processors. The third stage involves use of simple random sampling technique to select three communities from each of the three LGAs of the two states selected to obtain eighteen communities. From each of these communities, twelve respondents were randomly selected to give a sample size of two hundred and sixteen respondents for the fourth and final stage of the multi-stage sampling techniques proposed for this investigation. Questionnaires based on the objectives of the study were administered to the selected respondents with the assistance of trained enumerators during focus group sessions to obtain primary data for the study. A 5 point Likert-type scale of strongly agree (5), agree (4), undecided (3), disagree (2), strongly disagree (1) was used to determine respondents' perception of effects of inadequate information on selected modern shea butter 
processing technologies and very important (5), important (4), undecided (3), not important (2), not very important (1), for respondents' perceived information needs. Also, a 3 and 2 point Likert-type scale of always (3), sometimes (2), never (1), and aware (2), not aware (1), were used to determine respondents' sources of information and awareness of modern shea butter processing technologies. Respondents' level of awareness was determined by converting the means of the awareness indices to percentages. Data collected from the field were analysed using frequency counts, percentages, and weighted mean scores. Chi-square was also used to find the level of association between variables.

\section{Results and Discussion}

\subsection{Selected Socio-Economic Characteristics of Respondents}

Table 1 shows the distribution of shea butter processor' according to their selected socio-economics characteristics. The result revealed that females $(90.3 \%)$ were mostly involved in the processing of shea butter in the study areas. $83.4 \%$ of the respondents were agile youths of between the ages of 21 and 40 years, implying that there is a great prospect for increased and sustainable shea butter production in the study areas. Table 1 also revealed that $87 \%$ of the respondents were married whilst $46.8 \%$ of them had no formal education. However, $27.8 \%, 15.3 \%$ and $10.1 \%$ of them had primary, quranic and secondary school education respectively. From this finding, it can be deduced that most of the respondents had low level of education. This agrees with the finding of Igene et al, 2018. Table 1 further revealed that majority (63.1\%) of the respondents had processing experience of more than 15 years. From this result, it can be inferred that majority of the respondents' have experience in the processing of shea butter in the study areas.

Table 1. Distribution of respondents according to selected personal characteristics $(\mathrm{N}=216)$

\begin{tabular}{llll}
\hline S/N & Variables & Frequency & Percentage \\
\hline 1 & Sex & & \\
& Male & 21 & 9.7 \\
& Female & 195 & 90.3 \\
& Age & & \\
& Below 20 & - & - \\
& $21-30$ & 60 & 27.8 \\
& $31-40$ & 120 & 55.6 \\
& $41-50$ & 21 & 9.7 \\
& 51-60 & 14 & 6.5 \\
& Above 60 & 1 & 0.5 \\
Marital status & Single & & \\
& Married & 19 & 8.8 \\
& Divorced & 188 & 87 \\
& Widowed & 9 & 4.2 \\
Level of education & - & - \\
& No formal education & 101 & 46.8 \\
& Quranic & 33 & 15.3 \\
& Primary & 60 & 27.8 \\
& Secondary & 22 & 10.1 \\
Tertiary & Years of processing experience & & \\
1-5 & 12 & 5.6 \\
& 6-10 & 50 & 23.1 \\
11-15 & 16 & 7.4 \\
Above 15 & 138 & 63.9 \\
\hline & & &
\end{tabular}

Source: Field survey, 2016.

\subsection{Respondents'Awareness of Selected Modern Shea Butter Processing Technologies}

Table 2 shows the respondents' awareness of selected modern shea butter processing technologies. Results indicate that respondents were aware of some modern shea butter processing technologies such as shea kernel dryer (92\%), shea nut cracker and separator $(90 \%)$ and clarifier (81\%). However, the respondents were not aware 
of some important modern shea butter processing technologies such as kneader (91\%), disc mill (80\%), shea kernel roaster $(79 \%)$, manual screw press $(72 \%)$ and hammer mill crusher $(67 \%)$. This suggests that majority (52\%) of the respondents had low level of awareness on modern shea butter processing technologies. According to Oladeji and Oyesola (2000), farmers may be aware of certain farm practices, but may not know how to carry out such operations if there is no further information on the practices.

Table 2. Distribution of respondents' awareness of selected modern shea butter modern processing technologies $(\mathrm{N}=215)$

*Figures in parenthesis are percentages

\begin{tabular}{lll}
\hline Selected Modern Processing Technologies & \multicolumn{3}{l}{ Awareness } \\
\cline { 2 - 3 } & Aware & Not Aware \\
\hline Parboiled tank & $113(52)^{*}$ & $103(48)$ \\
Shea fruit digester & $115(53)$ & $101(47)$ \\
Shea kernel dryer & $199(92)$ & $17(8)$ \\
Shea nut cracker and separator & $194(90)$ & $22(10)$ \\
Shea kernel roaster & $46(21)$ & $170(79)$ \\
Hammer mill crusher & $71(33)$ & $145(67)$ \\
Disc mill & $43(20)$ & $173(80)$ \\
Kneader & $19(9)$ & $197(91)$ \\
Manual screw press & $60(28)$ & $156(72)$ \\
Decanting vessel & $117(54)$ & $99(46)$ \\
Clarifier & $175(81)$ & $41(19)$ \\
Storage tank & $107(50)$ & $109(51)$ \\
Awareness percentage mean score $(\bar{x})$ & 49 & 52 \\
\hline
\end{tabular}

Source: Field survey, 2016.

\subsection{Respondents' Sources of Information on the Selected Shea Butter Modern Processing Technologies}

Table 3 shows the respondents' sources of information on the selected modern processing technologies. Result indicates that Weighted mean score $(\bar{X}), 70,67,64$, and 63 of the respondents always got their information on the selected modern processing technologies from fellow processors, cooperative societies, friends and radio respectively. The result on the use of fellow processor as source of information agrees with the finding of Antholt (1994) who attributed the rise in farmers' preferring fellow farmers as a first-hand information source to the apparent ineffectiveness in the public extension services in developing countries. Also, the respondents sometimes got information from television (Weighted mean score $(\bar{X})=46$ ), extension agents (Weighted mean score $(\bar{X})=42$ ) and bulletin and posters (Weighted mean score $(\bar{X})=34$ ) respectively.

Table 3. Distribution of respondents' sources of information ( $\mathrm{N}=216)$.

\begin{tabular}{lll}
\hline Sources of information & Total weighted score & Weighted mean score $(\bar{x})$ \\
\hline Cooperative societies & 602 & 67 \\
Extension agents from (ADPs, NIFOR, RMRDC) & 385 & 42 \\
Fellow processors & 631 & 70 \\
Television & 413 & 46 \\
Radio & 564 & 63 \\
Internet & 217 & 24 \\
Bulletin and posters & 309 & 34 \\
Friends & 578 & 64 \\
GSM & 224 & 25 \\
Total weighted mean score & & 435 \\
Average weighted mean score $(\bar{x})$ & 48 \\
\hline
\end{tabular}

Always $=3$, sometimes $=2$, never $=1$.

Decision: $\geq 48=$ Always, $<48=$ Sometimes.

Source: Field survey, 2016. 


\subsection{Respondents' Information Needs on the Selected Shea Butter Processing Technologies}

Table 4 shows the distribution of respondent's areas of information needs on the selected shea butter processing technologies. The result revealed that respondents perceived information needs on some technologies as important such as kneading (Weighted mean score $(\bar{X})=89$ ), crushing (Weighted mean score $(\bar{X})=88$ ), roasting (Weighted mean score $(\bar{X})=85$ ), milling (Weighted mean score $(\bar{X})=84$ ), storing (Weighted mean score $(\bar{X})=83$ ) and extraction (Weighted mean score $(\bar{X})=81$ ). Some of the results in Table 3 are expected because when processors are not aware of certain technologies as reflected in Table 2, it is logical that they will definitely need information on such technologies so as to get better productivity from their processing activities. The result also shows that respondents perceived information needs on some technologies as not important such as shea fruit digesting (Weighted mean score $(\bar{X})=75$ ), boiling (Weighted mean score $(\bar{X})=74$ ), drying (Weighted mean score $(\bar{X})=73$ ) and scooping (Weighted mean score $(\bar{X})=67$ ).

Table 4. Distribution of respondents' perceived information needs on modern shea butter processing technologies $(\mathrm{N}=216)$

\begin{tabular}{lll}
\hline Information needs & Total weighted score & Weighted mean score $(\overline{\boldsymbol{X}})$ \\
\hline Boiling of fresh fruits using parboiled tank & 889 & 74 \\
Digesting of boiled fruits using shea fruit digester & 904 & 75 \\
Drying of nuts using shea kernel dryer & 876 & 73 \\
Cracking and separation of nuts using shea nut & 820 & 68 \\
cracker and separator & & \\
Roasting of kernels using shea kernel roaster & 1025 & 85 \\
Crushing of roasted kernels using hammer mill crusher & 1059 & 88 \\
Milling of crushed kernels using disc mill & 1008 & 84 \\
Kneading of milled kernels using kneader & 1064 & 89 \\
Extraction of shea butter oil using manual screw press & 972 & 81 \\
Scooping of shea butter oil using decanting vessel & 809 & 67 \\
Clarification of shea butter oil using clarifier & 774 & 65 \\
Storing of shea butter using storage tank & 998 & 83 \\
Total weighted mean score & & 932 \\
Average weighted mean score $(\bar{X})$ & & 78 \\
\hline
\end{tabular}

Very important $=5$, Important $=4$, Undecided $=3$, Not important $=2$, Not very important $=1$

Decision: $\geq 78=$ Important, $<78=$ Not important

Source: Field survey, 2016.

\subsection{Respondents' Perception on Effects of Inadequate Information on Modern Shea Butter Processing Technologies}

Table 5 shows the respondents' perception on the effects of inadequate information on modern shea butter processing technologies. The result indicates that respondents strongly agreed with some of the statements that the effects of inadequate information on the selected modern processing technologies were low yield of shea butter (Weighted mean score $(\bar{x})=78$ ), low income (Weighted mean score $(\bar{x})=76$ ), local use of local technologies (Weighted mean score $(\bar{X})=71$ ), poor packaging of shea butter (Weighted mean score $(\bar{X})=66$ ) and low standard of living (Weighted mean score $(\bar{X})=62$ ). However, they strongly disagreed that inadequate information will cause low patronage of shea butter products. 
Table 5. Distribution of respondents according to perceived effects of inadequate information on modern shea butter technologies $(\mathrm{N}=216)$

\begin{tabular}{lll}
\hline Effects of inadequate information & Total weighted score & Weighted mean score $(\overline{\boldsymbol{X}})$ \\
\hline Low income from sales of shea butter & 607 & 76 \\
Continuous use of local technologies & 570 & 71 \\
Inaccessibility to credit facilities & 479 & 60 \\
Low yield of shea butter & 626 & 78 \\
Low standard of living & 498 & 62 \\
Poor packaging of shea butter products & 531 & 66 \\
Unemployment & 321 & 40 \\
Low patronage of shea butter products & 296 & 37 \\
Total weighted mean score & & 490 \\
Average weighted mean score $(\bar{X})$ & & 61 \\
\hline
\end{tabular}

(Strongly agree $=5$, agree $=4$, undecided $=3$, disagree $=2$, strongly disagree $=1$ )

Decision: $\geq 61=$ strongly agree,$<61=$ strongly disagree

Source: Field survey, 2016.

\subsection{Relationship between Selected Socio-Economic Characteristics of Respondents and their Information Needs}

Table 6 shows the relationship between respondents' selected personal characteristics and their information needs. The result shows that there was a significant association between the respondents' sex $\left(\chi^{2}=85.983, \mathrm{p}<\right.$ $0.00)$ and their information needs. The significant association of respondents' sex with their information needs might be due to the fact that more females were involved in shea butter processing than the male processors in the study areas. Also, there was a significant association between the respondents' educational level $\left(\chi^{2}=86.983\right.$, $\mathrm{p}<0.00)$ and their information needs. This implies that respondents with good educational background will be more conversant with their information needs than those with low educational. This view is supported by Yahaya (2003) who posited that people with better education take more advantage of new sources of information than those with less education. Furthermore, significant association exist between respondents' information needs and years of processing experience $\left(\chi^{2}=22.076, p<0.00\right)$. This result is not unexpected as respondents with years of processing experience are expected to be conversant with their information needs than those with less years of processing experience.

Table 6. Relationship between processors' selected personal characteristics and their information needs

\begin{tabular}{lllll}
\hline Variables & $\left(\chi^{2}\right)$ & Df & p-value & Decision \\
\hline Sex & $\chi^{2}=22.076$ & 1 & 0.000 & Significant \\
Educational level & $\chi^{2}=86.983$ & 4 & 0.000 & Significant \\
Years of processing experience & $\chi^{2}=22.076$ & 3 & 0.000 & Significant \\
\hline
\end{tabular}

$\left(\chi^{2}\right)=$ Chi-square, $\overline{\mathrm{df}}=$ Degree of freedom, $\mathrm{p}=$ probability level of significance, $\mathrm{p} \leq 0.05$ (significant).

Source: Field survey, 2016.

\section{Conclusion}

Based on the findings of this study, it can be concluded that the processors were mostly females, young and married with low level of education. The study established that processors were aware of the importance of information in agricultural production as they were able to highlight the effects of inadequate information on modern shea butter processing technologies. The study also established that kneader, hammer mill crusher, shea kernel roaster, disc mill, storage tank and manual screw press were the vital areas of modern processing technologies processors required information on. In the same vein, the study established that television and extension agents have not been effective in disseminating information to shea butter processors as processors depended on fellow processors and cooperative societies as sources of information which probably caused their low level of information on modern shea butter processing technologies. Finally, significant association exists between respondents' sex, level of education and years of processing experience and their information needs. 


\section{Recommendations}

1. There is a need for Nigerian Institute for Oil Palm Research (NIFOR), Agricultural Development Programme (ADP), Raw Material Research Development Council (RMRDC) and the concerned Non-governmental Organisations (NGOs) to work together on how to disseminate adequate information to shea butter processors using extension methods such as field days, trade fair, demonstrations and posters.

2. In creating awareness of modern shea butter processing technologies in the study areas, identified areas of information needs should be given priority by the appropriate stakeholders.

\section{Acknowledgement}

We are grateful to the Management of Nigerian Institute for Oil Palm Research (NIFOR), Benin City, Edo State, Nigeria for providing funds to undertake this research work.

\section{References}

Adedoyi, S. T. (1990). Linkage in the development and delivery of agricultural research information by Nigerian Research Institutes. Unpublished Ph.D. Thesis in the Department of Communication and Language Arts, University of Ibadan, Nigeria, 69-71.

Aina, L.O. (2004). Library and information services to the neglected majority in Africa: The need for a restructuring of LIS curriculum in Africa. Proceeding of $16^{\text {th }}$ Standing Conference of Eastern, Central and Southern African Librarians, Kampala: Uganda Library, 57-60.

Ajayi, M. T., Banmeke, T. O. A., \& Solomon, O. (2010). Information needs of oil palm farmers in Esan Central Local Government Area of Edo State, Nigeria. Nigerian Journal of Rural Extension and Development, 3, 40-46.

Antholt, C. H. (1994). Getting ready for the $21^{\text {st }}$ century: Technical change and institutional modernization in agriculture, World Bank Technical Paper 217, Washington D.C.

Camble, E. (1992). Access to and utilisation of quality information in rural development programme in Bama Zone of Borno State. Unpublished Ph.D. Thesis, Department of Library, Archival and Information Studies, University of Ibadan, Nigeria, 35-39.

Eneh, M. C. C. (2010). An overview of shea nut and shea butter industry in Nigeria. Paper presented at the National Seminal Organized by Central Bank of Nigeria in collaboration with Federal Ministry of Agriculture and Rural Development and Nigeria Export Promotion Council (NEPC) Niger State; 4-5 August, 2010, 1-4.

Harris, P. J. C., Browne, A. W., Barret, H. R., \& Cadoret, K. (2001). Facilitating the inclusion of the resource-poor IN Organic Production and Trade: Opportunities and constraints posed by certification. Coventry: DFID/HDRA.

Igene, L., Sedibe, M. M., Van der Westhuizen, C., \& Solomon, O. (2018). Constraints hindering processors' effective access to training programmes on modern shea butter processing in Niger State, Nigeria. South Africa Journal of agricultural Science, 45(1), 26-33. http://dx.doi.org/10.17159/2413-3221/2018/v46n1a420.

Morris, C. D., \& Stilwell, C. (2003). Getting the write message right: Review of guidelines for producing readable print agricultural information materials South. African Journal of Library and Information Science, 69(1), 71-83.

Morrow, K., Nielsen, F., \& Wettasinha, C. (2002). Changing information flows. LEISA, 18(2), 4-5.

National Population Census, (2007). Population census interim report. A Publication of the National Population Commission, Abuja, Nigeria, 49-52.

Oladeji, J. O., \& Oyesola, O. B. (2000). Information needs of rice farmers on harvesting and processing activities in Obafemi Owode Local Government Area of Ogun State. Proceeding of Agricultural Extension Society of Nigeria (AESON) held at the Department of Agricultural Extension and Rural Development, University of Ibadan, 141-150.

Ololade, L. S., \& Ibrahim, F. A. (2014). Assessment of the contribution of shea butter processing to poverty reduction among women in Kwara State, Nigeria. Journal of Sustainable Development in Africa, 16(3), $1-12$. 
Ozowa, V. N. (2004). Information needs of small farmers in Africa. Nigeria Example. Quarterly Bulletin of the International Association of Agricultural Information Specialist. IAALD/CABI, 40(1), 52-57.

Stanley, K. N. (1990). A critique of information systems and services in Kenya and the role of Kenya National Library Services in their cooperation in Huttewmann I., and S. K. Mg'anga (eds). Coordinational of Information Systems and Services in Kenya, Bonn. Education Science and Documentation Centre, Bonn, $3-50$.

Yahaya, M. K. (2003) Development communication: Lesson from change and social engineering projects, Corporate Graphic Limited, Ibadan, 7-10.

\section{Copyrights}

Copyright for this article is retained by the author(s), with first publication rights granted to the journal.

This is an open-access article distributed under the terms and conditions of the Creative Commons Attribution license (http://creativecommons.org/licenses/by/3.0/). 